RESEARCH ARTICLE

\title{
Optimization of Process Parameters for Higher Recovery of Fuel Oil from Mixed Plastic Wastes
}

\author{
Selvaraj $\mathbf{M}^{1}$, Sriramajayam $\mathbf{S}^{* 1}$, Pugalendhi $\mathbf{S}^{1}$ and Ramesh $\mathbf{D}^{2}$ \\ *1Department of Renewable Energy Engineering, Tamil Nadu Agricultural University, Coimbatore-641 003. \\ ${ }^{2}$ HC\&RI (W) Trichy, Tamil Nadu Agricultural University, Coimbatore-641 003.
}

Received : $12^{\text {th }}$ May, 2020

Revised : $20^{\text {th }}$ May, 2020

Revised : $12^{\text {th }}$ June, 2020

Accepted : $24^{\text {th }}$ June, 2020

\begin{abstract}
Pyrolysis is an efficient method to convert plastic waste to fuel oil, pyrolytic gas, and solid residue. The yield of these products may vary with feedstock types and reaction conditions. The mixed plastic waste HDPE, LDPE and PP was selected and characterized for fuel oil synthesis. The moisture content and bulk density of mixed plastic wastes were found as $0.18 \%$ and $38 \%$, $\mathrm{Kgm}^{-3}$ respectively. Three reaction temperatures $\left(400,450\right.$, and $500^{\circ} \mathrm{C}$ ) were used in a pyrolytic reactor for optimizing the pyrolysis process. Results showed that the reaction temperature has a significant influence on fuel oil yield. The optimal reaction temperature for maximum fuel oil yield (84.7\%) from mixed plastic wastes was found at $500^{\circ} \mathrm{C}$ in the reactor. The fuel properties of fuel oil produced from plastics wastes are comparable with petrol and diesel fuels.
\end{abstract}

Keywords: Pyrolysis; plastic waste; fuel oil

\section{INTRODUCTION}

Plastics are non-biodegradable polymers used as packaging materials for household and domestic products, electrical and electronic goods, and building construction and automotive industries. Among different plastics, plastic carry bags are the most widely used. The consumption of plastic carry bags is fast with stable growth due to relatively low cost and durability (Singhabhandhu and Tezuka, 2010). The increase in demography and the improved living conditions of people led to a dramatic increase in the consumption of plastics worldwide.

Plastic has become a significant commodity on a global scale and has infiltrated almost every aspect of human life. An estimate shows that plastic production per annum is about 300 MT during 2017 (Miandad et al., 2016b, Ratnasari et al., 2017). The global plastic production is estimated to grow at a rate of $6 \%$ every year (Gourmelon, 2015). The historic growth in production has outpaced almost all other manufactured materials from 2 MT produced in 1950 to 322 million tonnes produced in 2015. The used plastics became wastes and mostly disposed of through incineration or landfilling methods or dumped into the environment. However, these methods have a negative impact on the environment, such as air/soil pollutions. In India, more than 10,000 tonnes of plastic wastes were generated every day, only $60 \%$ was recycled, and a balance of $40 \%$ was not possible to dispose of (Patni *Corresponding author's e-mail: ramajayam@gmail.com. et al., 2013). These plastic wastes pose a severe environmental challenge due to non-degradable. Hence, there is an urgent need to find effective ways to convert waste plastics into useful products.

Pyrolysis is one of the techniques used in plastic waste disposal to produce a variety of products (Khan et al., 2016). Three end products produced from pyrolysis of plastics wastes are fuel oil, pyrolytic gas, and solid residue. The product yields may vary with reaction conditions and type of feedstocks used (Haykiri-Acma et al., 2006). As an advantage, pyrolysis can treat the mixture of various types of plastics without separation. The fuel oil from waste plastic is a cheaper substitute for heavy oil and used in industrial boilers, furnace, burners, and power generators.

\section{MATERIAL AND METHODS}

The methodology employed and the methods adopted for the characterization of plastic wastes and fuel oil are described.

\section{Selection of plastic wastes}

Based on availability and safety concerns, four types of plastic waste, such as HDPE, LDPE, PP and mixed plastic waste were selected.

\section{Preparation of feedstock}

The selected mixed plastic waste was collected from the different locations of Coimbatore district, Tamil Nadu, India. 
These plastic wastes were cleaned with water and dried and size reduced to $2 \times 2 \mathrm{~cm}$.

\section{Characterization of selected plastic wastes}

The physical, chemical and thermal properties of the selected plastic wastes were studied as per the ASTM methods furnished in Table 1.

\section{Description of reactor and its operating procedure}

A pyrolytic reactor used for the experiments for fuel oil production from plastic wastes and the average value of three experimental trials were reported. The pyrolytic reactor setup consists of a controller for reaction temperature and time, pyrolysis unit, condenser and feed hopper screw auger feeding system (Prabha, 2017). For all trials, the feed rate of $1 \mathrm{~kg}$ of plastic wastes per hour was used. Generally, the factors affecting the yield and quality of fuel oil were temperature, reaction time, heating rate, particle size, feedstock composition and moisture content (Rehan et al., 2016; Troger et al., 2013; Nizami et al., 2016; Miandad et al., 2016a). The pyrolysis reaction temperature was in the range of $300-900^{\circ} \mathrm{C}$ to produce fuel oil from plastics (Rehan et al., 2017). The effect of temperature and reaction time on the yield and quality of fuel oil from a pyrolysis process must be investigated (Miandad et al., 2016b). For example, the yield of fuel oil, especially the styrene yield, increased with an initial increase in temperature and time, and after a specific temperature and time, the oil yield started to decrease (Miandad et al., 2016b). They studied three different reaction times for the pyrolysis of plastics and found that an insignificant difference in liquid oil production between the 75 and 120 min reaction times. Also, the extra reaction time shows a similar yield for oil and char as 75 min reaction time. Based on the literature, the reaction temperatures selected for the experiments were 400,450 , and $500{ }^{\circ} \mathrm{C}$ to study their influence on the yield of three end pyrolysis products. The nitrogen gas of $20 \mathrm{ml} \mathrm{min}^{-1}$ was supplied to the pyrolytic reactor to create pyrolysis conditions. Firstly, the feed hopper was filled with a known weight $(5 \mathrm{~kg}$ ) of plastic wastes. Secondly, the reactor was switched $\mathrm{ON}$ and allowed to reach the desired reaction temperature.
Thirdly, feed the plastic waste at the rate of $1 \mathrm{~kg} \mathrm{~h}^{-1}$ to the reactor with the help of a screw auger. Fourthly, the vapor generated from the thermal degradation of plastic wastes occurs, and it comes out of the reactor through the outlet pipe provided in the reactor. Finally, vapor was passed through a condenser, and the condensed liquid was collected in a container. The non-condensable gas was analyzed using a multi-gas analyzer. The reactor was switched OFF and allowed to cool. The solid residue produced from the pyrolysis of plastic wastes was collected after the experimental trials. The process flowchart explaining the steps involved in fuel oil production from plastic wastes is shown in figure 1. The yields of pyrolytic products such as fuel oil, solid residue, and pyrolytic gas were calculated as follows.

$$
\begin{gathered}
\begin{array}{c}
\text { Fuel oil } \\
\text { yield, } \%=
\end{array} \\
\begin{array}{c}
\text { Solid residue } \\
\text { yield, } \%=
\end{array}
\end{gathered} \quad \begin{gathered}
\text { Weight of plastic waste use } \\
\text { Weight of solid residue }
\end{gathered}
$$

The yield of pyrolytic gas was calculated by subtracting the sum of fuel oil yield (\%) and solid residue yield (\%) from 100. A portable multi-gas analyzer (Gasboard-3100, Cubic, China) was used to assess gas compositions such as $\mathrm{CO}, \mathrm{CO}_{2}, \mathrm{CH}_{4}$, $\mathrm{C}_{\mathrm{n}} \mathrm{H}_{\mathrm{n}}$, and $\mathrm{H}_{2}$.

\section{Characterization of pyrolytic products}

The specific gravity of test samples was determined using a specific gravity bottle (IS: 14481972). The Redwood viscometer used to determine the kinematic viscosity of oil as per the ASTM 44572 method. The flashpoint, carbon residue, and ash content of samples were determined as per ASTM D93, ASTM D524-IP14/65, and ASTM D 482 procedures. The octane number of samples was found with the help of an octane number analyzer (Model: ZX101C, Make: Zeltex, American).

\section{RESULTS AND DISCUSSION}

The experimental results for characterization and fuel oil production through the pyrolysis of plastic wastes are reported below.

Table 1. Methods employed to characterize the plastic wastes

\begin{tabular}{clrr}
\hline S.No & Name of the property & Instrument used & Method used \\
\hline 1 & Moisture content & Hot air oven & ASTM D3173 \\
2 & Volatile matter & Muffle furnace & ASTM D 3175-89 \\
3 & Ash content & Muffle furnace & ASTM D 3174-89 \\
4 & Fixed carbon & Muffle furnace & ASTM D 3172-89 \\
5 & Bulk Density & - & ASTM E-873-06 \\
6 & Calorific value (HHV) & Bomb calorimeter & ASTM D 2015-77 \\
\hline
\end{tabular}




\section{Characteristics of plastic wastes}

The different thermoplastic wastes such as HDPE, LDPE, PP, and mixed wastes were selected and characterized. The moisture content of the selected plastic wastes varied from 0.11 to $0.25 \%$. Moisture content was highest for LDPE among the selected plastic wastes. Generally, the plastic wastes do not absorb the moisture, and the test samples were found to be less than $0.3 \%$ (Table 2).

Table 2. Characteristics of different plastic wastes

\begin{tabular}{lrrrrrr}
\hline $\begin{array}{l}\text { Plastic } \\
\text { wastes }\end{array}$ & $\begin{array}{r}\text { Bulk } \\
\text { density, } \mathbf{~ k g ~ m}^{-3}\end{array}$ & $\begin{array}{r}\text { Higher heating } \\
\text { value, MJ kg }\end{array}$ & $\begin{array}{r}\text { Moisture } \\
\text { content, \% }\end{array}$ & $\begin{array}{r}\text { Volatile } \\
\text { Matter }\end{array}$ & $\begin{array}{r}\text { Ash content } \\
\text { cixed } \\
\text { carbon }\end{array}$ \\
\hline HDPE & 52 & 40.36 & 0.11 & 96.5 & 2.57 & 0.82 \\
LDPE & 43 & 42.10 & 0.25 & 97.9 & 1.71 & 0.14 \\
PP & 36 & 41.10 & 0.15 & 98.7 & 1.08 & 0.07 \\
Mixed & 38 & 40.98 & 0.18 & 97.6 & 1.72 & 0.50 \\
\hline
\end{tabular}

The results have coincided with the result of Park et al. (2012). Bulk density of tested plastic wastes ranged from 36 to $52 \mathrm{~kg} \mathrm{~m}^{-3}$. The variation in the bulk density for selected plastic wastes was due to their composition. The higher heating value of 42.1

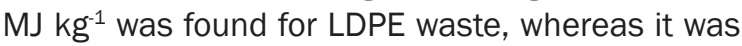
found as $40.98 \mathrm{MJ} \mathrm{kg}^{-1}$ for the mixed plastic wastes. Volatile matter in plastic wastes was highest in PP (98.7\%), followed by LDPE wastes (97.9\%) and mixed wastes (97.6\%). The higher and lower ash content values were found for HDPE wastes (2.57\%) and PP wastes (1.08\%), respectively. The ash content of mixed plastics waste was found closer to LDPE waste, which may be due to LDPE wastes in that plastic waste. The higher fixed carbon content of $(0.82 \%)$ as found in HDPE, whereas it was found as $(0.50 \%)$ for mixed plastic waste.

Table 3. Product yields on the pyrolysis of different plastic wastes

\begin{tabular}{|c|c|c|c|c|}
\hline Plastic wastes & Temperature ${ }^{\circ} \mathrm{C}$ & Fuel oil, \% & Solid residue, \% & Pyrolytic gas, \% \\
\hline & 400 & 77.3 & 7.8 & 14.9 \\
\hline \multirow[t]{3}{*}{ HDPE } & 450 & 78.2 & 4.9 & 16.9 \\
\hline & 500 & 79.8 & 1.3 & 18.9 \\
\hline & 400 & 70.5 & 8.1 & 21.4 \\
\hline \multirow[t]{3}{*}{ LDPE } & 450 & 79.2 & 5.9 & 14.9 \\
\hline & 500 & 81.7 & 4.2 & 14.1 \\
\hline & 400 & 80.8 & 4.3 & 14.9 \\
\hline \multirow[t]{3}{*}{ PP } & 450 & 84.3 & 1.6 & 14.1 \\
\hline & 500 & 88.2 & 0.9 & 10.9 \\
\hline & 400 & 81.6 & 4.1 & 14.3 \\
\hline \multirow[t]{2}{*}{ Mixed } & 450 & 82.3 & 1.9 & 15.8 \\
\hline & 500 & 84.7 & 1.2 & 14.1 \\
\hline
\end{tabular}

\section{Pyrolysis of plastic wastes}

The yield of pyrolytic products (fuel oil, solid residue, and pyrolytic gas) obtained from the pyrolysis of different plastic wastes at selected reaction temperatures $\left(400,450\right.$, and $\left.500^{\circ} \mathrm{C}\right)$ is presented in Table 3. For HDPE wastes, the yield of fuel oil production was increased with reaction temperature. For instance, the fuel oil yield for HDPE wastes at 400 and $500^{\circ} \mathrm{C}$ was 77.3 and $79.8 \%$. In the case of LDPE waste, the fuel oil yield at 400 and $500^{\circ} \mathrm{C}$ was 70.5 and $81.7 \%$, respectively. For PP wastes, the fuel oil yield at 400 and $500^{\circ} \mathrm{C}$ was 80.8 and $88.2 \%$, respectively. The fuel oil yield for mixed plastic waste at 400 and $500^{\circ} \mathrm{C}$ was 81.6 and $84.7 \%$, respectively. Further, the fuel oil yield recorded for the tested plastic wastes was enhanced with an increase in reaction temperature. Interesting to note that solid residue was followed a declining trend with an increase in reaction temperature for all plastic wastes. The pyrolytic gas (non-condensable gas) yield was varied with reaction temperature for all plastic wastes. The maximum fuel oil obtained from the mixed plastic wastes was $84.7 \%$ at $500^{\circ} \mathrm{C}$. The variation in the pyrolytic products observed was mainly due to different types of plastic waste and their compositions.

\section{Gas composition}

The compositions of pyrolytic gas obtained at three different operating temperatures were 
analyzed using portable exhaust gas, and results are presented in Table 4. The results of multigas analyzer were shows the presence of carbon monoxide $(\mathrm{CO})$, methane $\left(\mathrm{CH}_{4}\right)$, hydrocarbon $\left(\mathrm{C}_{n} \mathrm{H}_{n}\right)$, hydrogen $\left(\mathrm{H}_{2}\right)$ and carbon dioxide $\left(\mathrm{CO}_{2}\right)$ in the pyrolytic gas, which was produced from tested plastic wastes under pyrolysis process.

Table 4. Details of Pyrolytic gas composition

\begin{tabular}{lcccccc}
\hline \multirow{2}{*}{ Plastic Wastes } & \multicolumn{7}{c}{ Temperature, $\mathrm{C}$} & $\mathrm{CO}$ & $\mathrm{CH}_{4}$ & $\mathrm{C}_{\mathrm{n}} \mathrm{H}_{\mathrm{n}}$ & $\mathrm{H}_{2}$ & $\mathrm{CO}_{2}$ \\
\hline \multirow{3}{*}{ HDPE } & 400 & 15.2 & 21.3 & 6.7 & 1.9 & 9.2 \\
& 450 & 10.2 & 30.5 & 5.7 & 5.7 & 5.2 \\
& 500 & 7.20 & 10.9 & 5.2 & 5.2 & 4.1 \\
LDPE & 400 & 10.2 & 32.4 & 10.3 & 4.7 & 4.9 \\
& 450 & 4.30 & 35.7 & 13.9 & 5.7 & 4.2 \\
& 500 & 10.9 & 27.5 & 10.9 & 5.3 & 6.7 \\
PP & 400 & 11.2 & 29.3 & 13.2 & 4.2 & 6.7 \\
& 450 & 9.50 & 32.3 & 13.8 & 6.7 & 4.2 \\
& 500 & 5.20 & 39.5 & 13.2 & 5.7 & 2.5 \\
Mixed & 400 & 10.7 & 31.2 & 11.3 & 4.6 & 5.2 \\
& 450 & 9.20 & 36.4 & 12.8 & 5.2 & 4.7 \\
\hline
\end{tabular}

There was a variation in values noticed for the gas composition in the pyrolytic gas. This might be due to the difference in feedstock compositions and reaction temperature used in the experiments. The primary gas compositions in the pyrolytic gas were methane and hydrocarbons, ranging from 10.09 to $39.5 \%$ and 5.2 to $13.9 \%$, respectively. The $\mathrm{H}_{2}$ present in the pyrolytic gas was varied as 1.9 to 6.7 $\%$ for tested plastic wastes.

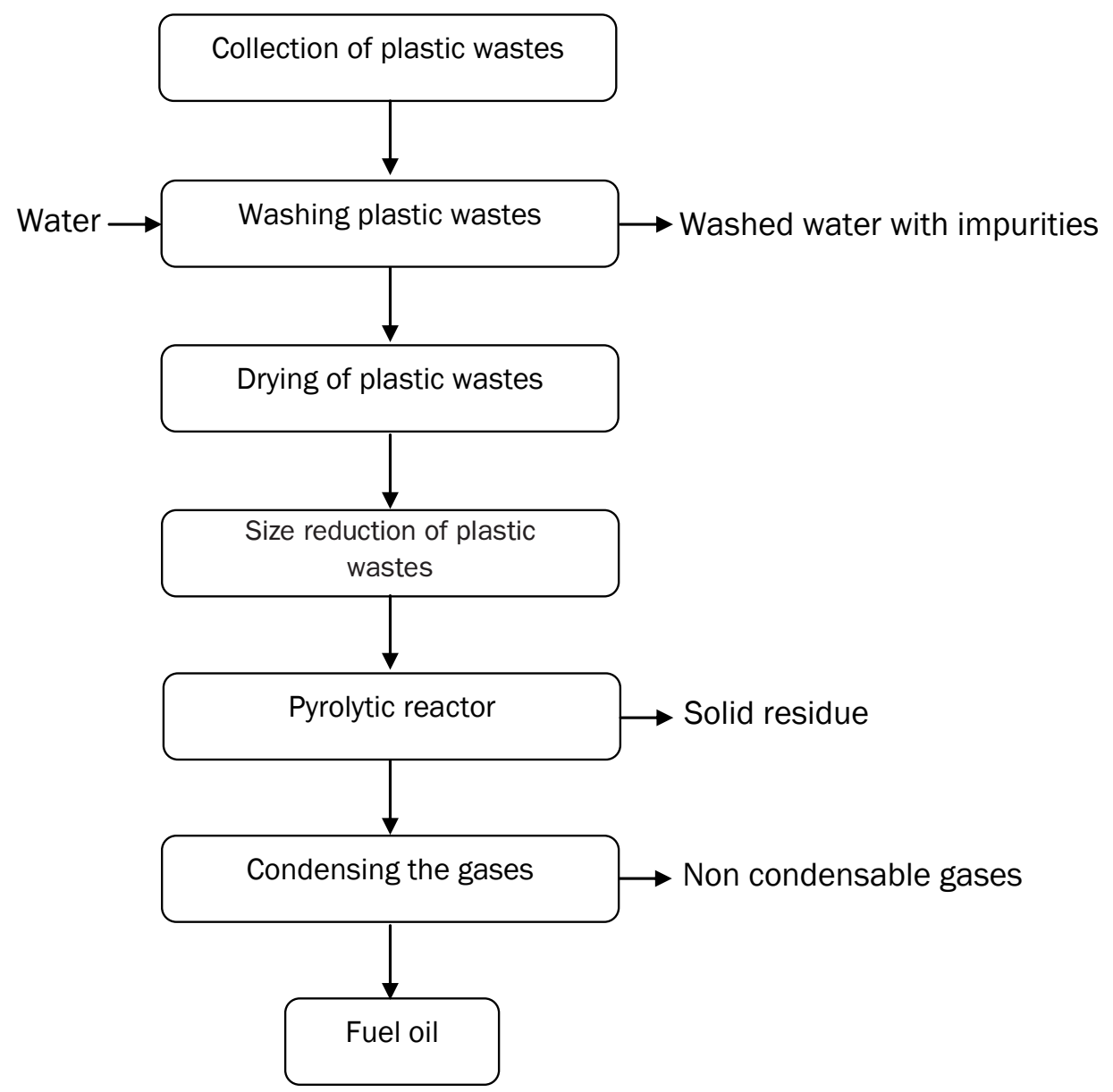

Figure 1. Process flowchart for fuel oil production from plastic wastes using pyrolysis process 
Table 5. The properties of fuel oil produced from different plastics wastes

\begin{tabular}{|c|c|c|c|c|c|c|}
\hline \multirow{2}{*}{ Properties } & \multicolumn{4}{|c|}{ Fuel oil } & \multirow{2}{*}{$\begin{array}{c}\text { Petrol } \\
\text { (Ahmad et al., } \\
\text { 2014) } \\
\end{array}$} & \multirow{2}{*}{$\begin{array}{c}\text { Diesel } \\
\text { (Ahmad et } \\
\text { al., 2014) }\end{array}$} \\
\hline & HDPE & LDPE & PP & Mixed & & \\
\hline Specific gravity & 0.804 & 0.814 & 0.789 & 0.802 & $0.720-0.780$ & $0.82-0.85$ \\
\hline Kinematic viscosity @ $40^{\circ} \mathrm{C}$, cSt & 4.72 & 4.68 & 3.68 & 4.12 & 1.17 & $1.9-4.1$ \\
\hline Calorific value, MJ kg-1 & 43.6 & 45.62 & 44.62 & 44.52 & $42-46$ & $42-45$ \\
\hline Flashpoint, ${ }^{\circ} \mathrm{C}$ & 49 & 44 & 35 & 43 & 42 & 52 \\
\hline Ash Content, \% & 0.0039 & 0.0040 & 0.0038 & 0.0039 & - & 0.01 \\
\hline Carbon Residue, \% & 0.58 & 0.61 & 0.59 & 0.60 & - & 0.20 \\
\hline Octane Number & 93.4 & 94.2 & 98.7 & 97.6 & 92 & - \\
\hline
\end{tabular}

\section{Characterization of pyrolytic fuel oil}

The physical and chemical properties of fuel oil produced from the pyrolysis of plastic wastes are presented in Table 5. The specific gravity for the fuel oil produced from mixed plastic wastes was recorded as 0.802 , which was closer value to that of petrol and diesel fuels. The kinematic viscosity of the fuel oil produced from mixed plastic wastes was noted as $4.12 \mathrm{cSt}$, which was higher than that of petrol and diesel fuels. The higher heating value of fuel oil produced from mixed plastic wastes (44.52 $\mathrm{MJ} \mathrm{kg}^{-1}$ ) was comparable with petrol and diesel fuels $\left(42-46 \mathrm{MJ} \mathrm{kg}^{-1}\right)$. Flashpoint of fuel oil $\left(43^{\circ} \mathrm{C}\right)$ derived from mixed plastic wastes was found to be closer to that of diesel and petrol, respectively. Ash content was very low compared to diesel. The value of carbon residue of fuel oil was closer to the diesel. The octane number of fuel oil was closer to petrol.

\section{CONCLUSION}

The present study investigated the influence of reaction temperature on fuel oil yield in pyrolysis of four different plastic wastes using a pyrolytic reactor. Bulk density of selected plastic wastes ranged from 36 to $52 \mathrm{~kg} \mathrm{~m}^{-3}$. HDPE wastes have a higher bulk density $\left(52 \mathrm{~kg} \mathrm{~m}^{-3}\right)$ compared with other plastic wastes (LDPE and PP). The higher heating value of 42.10 MJ kg ${ }^{-1}$ was found in LDPE wastes followed by PP wastes (41.10 MJ kg-1), HDPE (40.36 $\mathrm{MJ} \mathrm{kg}^{-1}$ ) and $40.98 \mathrm{MJ} \mathrm{kg}^{-1}$ for mixed plastic waste. Volatile matter in plastic wastes was highest in PP (98.7\%), followed by LDPE wastes (98.2\%) and mixed wastes (97.6\%). The ash content was lowest in PP wastes (1.08) and highest in HDPE wastes in 2.57\%; further mixed plastic waste has shown 1.72 percent, respectively. HDPE plastic wastes had the highest fixed carbon $(0.93 \%)$ followed by mixed plastic wastes $(0.68 \%)$, PP (0.22 \%), and LDPE wastes (0.09\%). The maximum fuel oil yield obtained at $500^{\circ} \mathrm{C}$ in the reactor for all the selected plastic wastes. The maximum fuel oil yield recorded as $79.8,80.8,84.7$, and 88.2 $\%$ for HDPE, LDPE, mixed, and PP plastic wastes, respectively.

\section{REFERENCES}

Ahmad, I., M. I. Khan, H. Khan, M. Ishaq, R. Tariq, K. Gul. (2014). Pyrolysis study of polypropylene and polyethylene into premium oil products. Int. J. Green Energy, 12: 663-7

Gourmelon, G. (2015). Global plastic production rises, recycling lags. New Worldwatch Institute analysis explores trends in global plastic consumption and recycling. Recuperado de http://www. worldwatch. org, 208.

Haykiri-Acma, H., Yaman, S., \& Kucukbayrak, S. (2006). Effect of heating rate on the pyrolysis yields of rapeseed. Renewable Energy, 31(6): 803-810.

Khan, M., Sultana, M., Al-Mamun, M., \& Hasan, M. (2016). Pyrolytic waste plastic oil and its diesel blend: fuel characterization. Journal of environmental and public health, 2016.

Miandad, R., Barakat, M.A., Aburiazaiza, A.S., Rehan, M., Ismail, I.M.I., Nizami, A.S. (2016a). Effect of plastic waste types on pyrolysis liquid oil. Int. Biodeterior. Biodegrad. http://dx.doi. org/10.1016/j.ibiod.2016.09.017.

Miandad, R., Barakat, M.A., Aburiazaiza, A. S., Rehan, M., and Nizami, A.S. (2016b). Catalytic pyrolysis of plastic waste: a review. Process Safety Environ. Protect. 102, 822-838. doi: 10.1016/j. psep.2016.06.022.

Nizami, A.S., Shahzad, K., Rehan, M., Ouda, O.K.M., Khan, M.Z., Ismail, I.M.I., Almeelbi, T., Basahi, J.M., Demirbas, A., 2016. Developing waste biorefinery in Makkah: a way forward to convert urban waste into renewable energy. Appl. Energy. DOI:10.1016/j.apenergy.2016.04.116.

Park, S. S., D. K. Seo, S. H. Lee, T-U. Yu, and J. Hwang. (2012). Study on pyrolysis characteristics of refuse plastic fuel using lab-scale tube furnace and thermogravimetric analysis reactor. J Anal Appl Pyrol., 97: 29-38.

Prabha. B., (2017). Design and development of pyrolytic reactor for fuel oil recovery from plastic wastes. Ph.D. Thesis, TNAU, Coimbatore.

Ratnasari, D.K., Nahil, M.A., and Williams, P. T. (2017). Catalytic pyrolysis of waste plastics using staged catalysis for production of gasoline range hydrocarbon oils. J. Anal. Appl. Pyrolysis 124: 631-637. doi: 10.1016/j.jaap.2016.12.027 
Rehan, M., Miandad, R., Barakat, M.A., Ismail, I.M. I., Almeelbi, T., Gardy, J.(2017). Effect of zeolite catalysts on pyrolysis liquid oil. Int. Biodeterior. Biodegrad. 119: 162-175. doi: 10.1016/j.ibiod. 2016.11.015.

Rehan, M., Nizami, A.S., Shahzad, K., Ouda, O.K.M., Ismail, I.M.I., Almeelbi, T., Iqbal, T., Demirbas, A. (2016). Pyrolytic liquid fuel: a source of renewable energy in Makkah. Energy Sour., Part A: Recov. Utiliz. Environ. Effects 38(17): 2598-2603. DOI: 10.1080/15567036.2016.1153753.
Singhabhandhu, A., and T. Tezuka. (2010). The wasteto-energy framework for integrated multi-waste utilization: Waste cooking oil, waste lubricating oil, and waste plastics. Energy, 35: 2544-2551.

Troger, N., Richter, D., \& Stahl, R. (2013). Effect of feedstock composition on product yields and energy recovery rates of fast pyrolysis products from different straw types. Journal of Analytical and Applied Pyrolysis, 100: 158-165. 